\title{
Evaluation of the Clinical Efficiency of an Antisickling Polyherbal Formula Drepanoalpha in a Sickle cell disease Patient in Gbado-Lite City (Democratic Republic of the Congo) by Quantum Magnetic Resonance Analyzer
}

\author{
Benjamin Gbolo Zoawe ${ }^{1,2}$, Koto-te-Nyiwa Ngbolua ${ }^{1,2, *}$, Pius T. Mpiana ${ }^{1,3}$, Ndanga \\ Bikibo Appolinaire ${ }^{1}$, Pangodi Aundagba Jean-Marie ${ }^{1}$, Masengo Ashande Colette ${ }^{1}$, \\ Mudogo Virima ${ }^{1,3}$ \\ ${ }^{1}$ Research Group in "Ethnopharmacology and Unconventional Medicine", \\ University of Gbado-Lite, Gbado-Lite, Democratic Republic of the Congo \\ ${ }^{2}$ Department of Biology, Faculty of Science, University of Kinshasa, Kinshasa, \\ Democratic Republic of the Congo \\ ${ }^{3}$ Department of Chemistry, Faculty of Science, University of Kinshasa, Kinshasa, \\ Democratic Republic of the Congo \\ *Corresponding author: Prof. Koto-te-Nyiwa Ngbolua (PhD); jpngbolua@unikin.ac.cd
}

\begin{abstract}
Sickle cell disease is a genetic disease linked to the presence of hemoglobin $S$ in the blood and is a major public health problem in Africa. The drugs available are expensive in view of the purchasing power of the majority of the population. The aim of this study was to assess the clinical efficacy of an improved traditional medicine called Drepanoalpha (an anti-sickle cell polyherbal formula) in a homozygous sickle patient using the quantum magnetic resonance analyzer. The results show the relevance of the use of this unconventional technical approach in the sickle cell disease patient treatment evaluation. Indeed, this study showed that Drepanoalpha is effective in vivo and restored homeostatic balance by optimizing some vital functions in the treated patient. The quantum magnetic resonance analyzer is therefore an important away which allows understanding the disorders of the body due to sickle cell disease and their correction post-treatment. It is desirable that the use of this device be validated in the evaluation of the effectiveness of anti-sickling drugs in large-scale clinical trials in rural areas like Nord-Ubangi province. Indeed, this instrument is not only fast, practical, economical, accessible, non-invasive but also easy to use and suitable for this category of research in underprivileged areas. The results obtained are in perfect agreement with the facts observed (recovery of some vital parameters and disappearance of seizures in the patient).

Keywords: Unconventional medicine; quantum magnetic resonance analyzer; sickle cell disease; nutraceuticals; therapeutic efficacy
\end{abstract}

\section{Introduction}

Sickle cell disease or SS anemia is a hereditary hemoglobinopathy linked to the presence of hemoglobin $\mathrm{S}$ in the blood and is a major public health problem in endemic areas. The available medicines are imported, making them expensive in view of the purchasing power of the majority of the population. For more than a decade, our team has been conducting rigorous scientific research on plants used in Traditional Medicine to treat this pathology. These studies led to the formulation of a polyherbal based medicinal plants food in the Democratic Republic of the Congo (DRC) called Drepanoalpha [1-4]. It is a drug whose efficacy has already been scientifically validated in vitro and in vivo and its toxicity limits are well known. Recent reports of total disappearance of seizures among homozygous sickle cell patients who have been treated with Drepanoalpha have been reported by patients or their families across the DRC (Abumombazi, Bukavu, Gbado-Lite, Gemena, Goma, Kinshasa, Lubumbashi, etc.). It has been observed that in more than 100 treated patients, the phenotypic profile is the same as that of normal individuals, 
suggesting that this would be an epigenetic modulation of the gene. This medication is given after prior infusion of one to two teaspoons of the powder in boiling water and should be administered within hours of its preparation. The volume of administration is $20 \mathrm{~mL}$ with remarkable pharmacological effects in sickle cell patients [5-11]. However, conventional methods of assessing the therapeutic efficacy and safety of improved traditional drugs are expensive because of laboratory consumables (chemical reagents) and equipment, and which, in besides, do not exist in the universities of the hinterland; however, they must train community managers and conduct high-level scientific research in the absence of state and laboratory grants. For this purpose, quantum magnetic resonance (RMQ) is a technique of choice for monitoring treatment in order to disprove or confirm the therapeutic efficacy and safety of a phytodrug in patients. It is a fast, non-invasive and painless technique that does not use chemical reagents but simply exploits the body's electromagnetic properties using an electronic sensor coupled with the RMQ analyzer and a computer [12-14]. This study was initiated with the aim of validating and promoting the use of RMQ in the monitoring of phytotherapeutic management of sickle cell disease in African rural zones and also as a simple, robust, alternative and/or follow-up of clinical trials in sickle cell patients. Given the limitations of the use of conventional methods in assessing the clinical effectiveness of plant derived medicines in rural areas, RMQ can provide a unique opportunity. This study is a major contribution to clinical trials using an unconventional method. To the best of our knowledge, the evaluation of the therapeutic efficacy of Drepanoalpha by this unconventional methodological approach in a homozygous sickle cell disease (SCD) patient is an original strategy of clinical studies never carried for such screening in the DRC.

\subsection{Place of study}

\section{Material and Methods}

This study was conducted in Gbado-Lite city in the Nord-Ubangi province (Figure 1) in the Democratic Republic of the Congo.

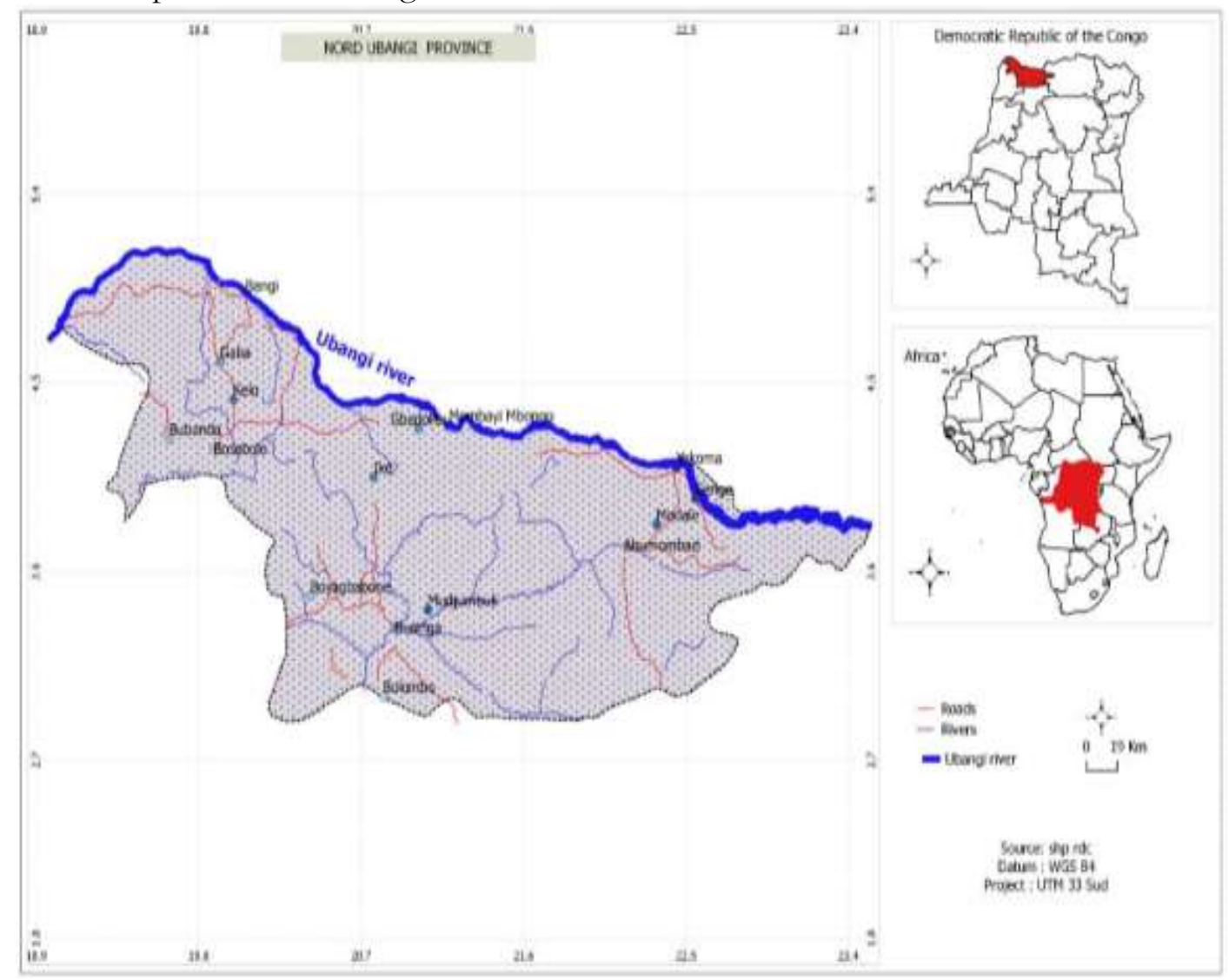

Figure 1. North Ubangi Province 


\section{a. Sickle Cell Anemia Patient}

The 13-year-old female patient (size: $110 \mathrm{~cm}$; weight: $30 \mathrm{~kg}$ ) was received in our research unit "Ethnopharmacology and unconventional Medicine" attached to the University Medical Center of University of Gbado-Lite, DRC in May 06, 2019 for painful seizures (vaso-occlusion) and hemolytic anemia. Result of Emmel test revealed SCD status. The SCD patient had received first aid at the Gbado-Lite General Reference Hospital (HGR) where he received symptomatic treatment. When he arrived at the University medical center, accompanied by his father, the hemoglobin level was $6 \%$ and the patient had splenomegaly and jaundice and has never been transfused since birth. His father admits to having previously submitted successfully her child to Drepanoalpha treatment in 2016 and that the child had no pain crisis longer known until he was admitted to HGR.

\section{b. Drepanoalpha (An innovative antisickling polyherbal formula)}

Drepanoalpha is an anti-sickle cell dietary supplement that supplements SCD patient nutrition with essential proteins and trace elements. His powder contains $17 \%$ proteins, $5.70 \%$ fat, $6 \%$ raw fibre and $55.33 \%$ carbon hydrates and presents an energy value of $1482.07 \mathrm{~kJ}$.

In addition, this nutraceutical contains in its composition the iron $(9.0 \mathrm{mg} / 100 \mathrm{~g})$, magnesium (1.4 mg/100 g), calcium ( $4.8 \mathrm{mg} / 100 \mathrm{~g})$, zinc, manganese, potassium, phosphorus and vitamin C. phytochemical Studies showed that anthocyanins and organic acids are the main active principles of Drepanoalpha. In addition, flavonoids are plentiful in Drepanoalpha and can be proposed as phytomarkers for quality control and the standardization of this dietary supplement. In addition to its nutritional properties, Drepanoalpha showed an ability to increase the hemoglobin level in vivo and antisickling activity (normalization rate: 80\%), anti-hemolytic and antioxidant properties $\left(\mathrm{DE}_{50}: 0.604 \pm 0.028 \mu \mathrm{g} / \mathrm{mL}\right)$. Drepanoalpha reduces the frequency of sickle cell attacks and improves the general state of treated patients. With a lethal dose (DL $\left.{ }_{50}\right)$ greater than $4,000 \mathrm{mg} / \mathrm{kg}$ in the Wistar rat and $16,000 \mathrm{mg} / \mathrm{kg}$ in the guinea pigs, the product may be considered non-toxic under the normal conditions of its use. In addition, the product did not show any toxicity on immune cells and blood coagulation factors. Forits use, it is necessary to place in a cup about $80 \mathrm{~mL}$ boiling water and add the amount of the powder of Drepanoalpha corresponding to the patient's age, i.e. 1 to 2 teaspoons. After infusion for 30 minutes, the surnageant is collected after filtration using a tea sieve or a very clean cloth. The resulting infuse will be administered three times a day at a rate of $20 \mathrm{~mL}$ per intake. This infuse cannot be used beyond 24 hours after its preparation. To be effective, Drepanoalpha should be consumed continuously for at least 6 months; it was only after that will give the maintaining doses [5-11].

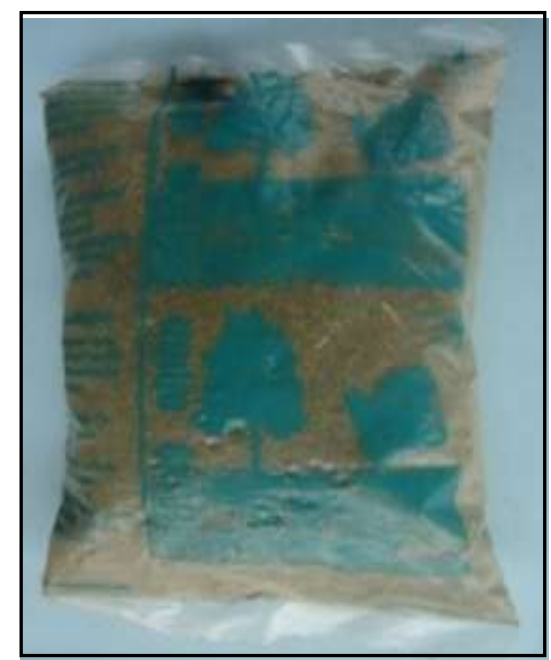

Figure 2. 1Drepanoalpha Powder 


\section{Methodology}

The mini-quantum analyzer performs a systematic scan of the human body. Electromagnetic signals emitted by the human body (a reflection of its normal or pathological state) are collected by an electronic sensor, amplified and processed by a microprocessor. The data collected is then compared by the software with the RMQ spectrum based on the principles of Fourier serial decomposition.

The main elements of analysis relate to about 40 parameters, of which cardiovascular systems and cerebro-vascular, bone mineral density, trace elements, nerves cranial, the gastrointestinal function, function of the large intestine, liver function, gallbladder function, pancreatic function, kidney function, the pulmonary function, brain, bone growth index, the endocrine system, the immune system, etc. The test is done before the meal or an hour later in an elongated position as showed in figure 3 and by ridding the patient of any metal objects and other electronic devices. The patient takes in his left or right hand the electronic sensor coupled with the RMQ and a personal computer as described by the manufacturer of the RMQ device [12-14]. The data was taken on $\mathrm{D}$-dayo Base line and $\mathrm{J}_{21}$ post treatment. The duration of treatment was seven days $\left(\mathrm{J}_{1}-\mathrm{J}_{7}\right)$

After scanning the human body, the results are automatically displayed on the computer screen and can be recorded or printed.

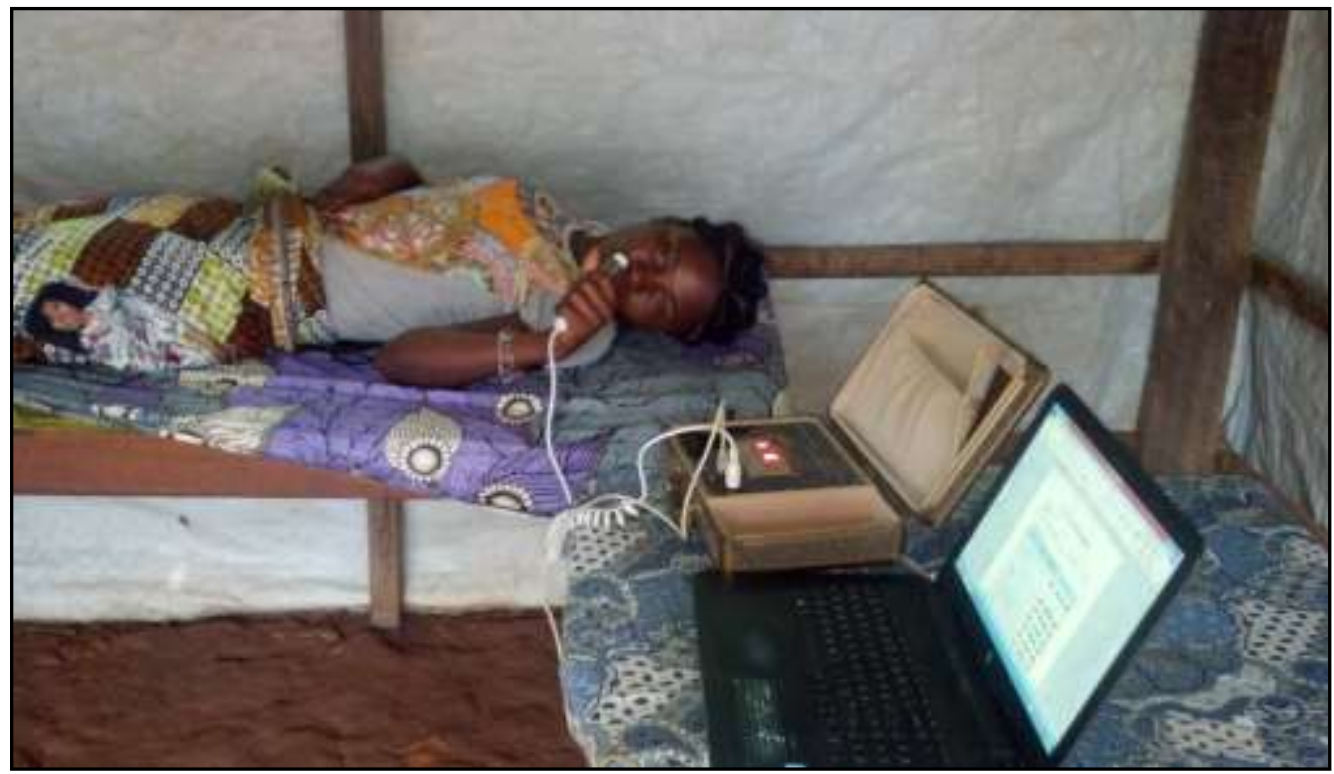

Figure 2.RMQ Analyzer

\section{Discussion}

The results of the RMQ analyses indicate that for some parameters, the values were not influenced by the taking of Drepanoalpha. While for others, the parameter values have been corrected from abnormally low or high values to normal benchmarks. These observations confirm the safety and therapeutic efficacy of Drepanoalpha in homozygous SCD patient as previously validated by conventional techniques in SS erythrocytes, rats; guinea pigs and homozygous SCD patients' model systems $[6,8,10,11]$.

The safety results in the absence of alteration of the values of vital organs (unchanged values) indicating that Drepanoalpha does not interfere with the functions of vital organs (kidneys, liver, brain, etc.): Cardiovascular and cerebrovascular systems, gastrointestinal function, liver 
function, gallbladder function, pancreatic function, kidney anointing, lung function, bone mineral density, brain, rheumatism, blood sugar, amino acid, skin, eyes, thyroid, etc. While, efficiency therapeutic results in the normalization of the values of parameters assessed from the body or organs emitting electromagnetic waves obtained by an electronic sensor coupled with the RMQ.

These values provide information on the state of the body or organ: healthy (normal value) or pathological condition (anomaly: abnormally low or high relative to normal/reference). This study revealed that Drepanoalpha is effective in vivo and has restored homeostatic balance by optimizing certain vital functions in the treated SCD patient. Indeed, Drepanoalpha has improved the function of the large intestine by normalizing the coefficient function of peristalsis function of the large intestine, the rate of absorption of the colon and the coefficient of bacteria. For the latter parameter the decrease in its value from 13,797 to 2,611 means that treatment with Drepanoalpha reduces the incidence of bacterial infections in the SCD patient. Taking the infused based nutraceutical improved the functioning of the cranial nerves and the memory index at the level of the patient's brain, bone mineral density. The polyherbal formula also helps to prevent rheumatism by improving the coefficient of hyperostosis and the coefficient of osteoporosis. Bone growth index values include bone alkaline phosphatase, osteocalcin, long bone healing status and epiphysic line; 17 mineral elements (Fe, Zn, Se, Cu, Co, Mn, I 2 , Ni, Fluore, P, K, Mg, Vanadium, Sn, Si, Sr and Bore); 8 vitamins ( $\left.A, D_{3}, E, K, B_{1}, B_{3}, B_{12}, C\right) ; 5$ coenzymes (biotin, pantothenic acid, folic acid, nicotinamide) and glutathione were standardized/normalized. It should also be noted that the consumption of Drepanoalpha also improved the endocrine system (thyroid index, adrenal gland index, pituitary secretion index, pineal secretion index, glandular secretion index, thymus) and the immune system (amygdala immune index, bone marrow index, spleen index: from 253,757 to 35,637 , index of immune system, index of immune gastrointestinal tract) of the SCD patient.

The reduction in the index value of the spleen is evidence that Drepanoalpha reduced the rate of sickle cell disease in vivo and would therefore prevent splenic sequestration of sickle cell cars reported in the literature as a factor responsible for splenomegaly in SCD patients [15]. The results of this study also show that Drepanoalpha improves the physical quality base of sickle cell disease. Indeed, this phytodrug reduced the response capacity index (from 288,094 to 65,419) respectively, the lack of water (from 323,023 to 37,637) and Index of hypoxia (from1208, 137 to 141,467). This shows that Drepanoalpha improves the state of hydration and oxygenation ofsickle celletirocytics and confirms that the bioactive molecules contained in Drepanoalpha would inhibit on the one hand, falciformation by interfering with the polymerization of deoxyhemoglobin $S$ and the Gardos canal reported in the literature as a factor implicated in erythrocytic dehydration [16] on the other hand.

The results of the RMQ analysis also indicate that Drepanoalpha prevents obesity in patients by reducing the lipid metabolism coefficient (from 3,954 to 3,708) and fat tissue colour coefficient (from 11,555 to 4,197).

Based on the results of this study, Drepanoalpha reduces proportion of collagen (at the level of certain systems and devices in the body) as well as the body's main and collateral channels; decreases systolic volume (from 195,026 to 67,882), low-density lipoprotein (C-LDL: from 7,301 to 1,578 ); estrogen (from 11,084 to 8,828), gonadotropin (from 20,534 to 8.93), prolactin (from 8,101 to 7,846 ), progesterone (from 64,712 to 16,724 ) and neurotransmitters (from 3,168 to 0.973).The standardization of C-LDL and neurotransmitters by Drepanoalpha allows trait prevent respectively atherosclerosis and inflammation in sickle cell disease. To this end, it should be noted that various inflammatory agents are often increased in SCD patients and are likely to cause a kidney dysfunction [17]. 


\section{Conclusion}

The aim of the present study was to evaluate the clinical efficacy of Drepanoalpha, an antisickle cell nutraceutical, in a homozygous SCD patient using the RMQ analyzer. The results show the relevance of the use of this unconventional analysis in the SCD patient under treatment. The RMQ analyzer being a reliable way to understand the body's disorders in a holistic way (deficiency, balance or excess), it can be validated as an appropriate and robust means for monitoring and evaluating the effectiveness of anti-sickle cell drugs in large-scale clinical studies (nutritherapy program) in rural areas. This device is not only fast, practical, economical, accessible, non-invasive but also easy to use and adapted for this category of research in underprivileged areas.

\section{References}

[1] Ngbolua KN, Mpiana PT, Mudogo V, 2019. Chemical and pharmacological studies of Drepanoalpha: Powerful anti-sickle cell dietary supplement developed in the Democratic Republic of Congo. European University Editions, Riga: Latvia. ISBN: 978-613-8-464365.

[2] Ngbolua KN, Tshilanda DD, Djolu RD, Falanga MC, Masengo AC, Tshibangu DST, Iteku BJ, Mudogo V, Mpiana PT. Anti-Sickle Cell Anemia and Bacterial Inhibitory Effects of Uvariodendron molundense (Diels) R.E.Fr. (Annonaceae) from Ubangi River Basin, DR Congo. Journal of Biosciences and Medicines. 2017; 5: 71-84.

[3] Ngbolua KN, Mpiana PT, Akoundze BJ, Mwanza BF, Tshibangu DST, Masengo CA, Liesse L, Takaisi K. Anti-sickling and bacterial inhibitory effects of two medicinal foods from the Congo River basin: Gnetum africanum Welw. (Gnetaceae) and Grewia coriacea Mast. (Malvaceae). Current Traditional Medicine 2016; 2(1): 34-41.

[4] Mpiana PT, Ngbolua KN, Tshibangu DST. Alicaments and sickle cell disease: A mini review. Chemistry Reviews. 2016;1 (6):884-89.

[5] Ngbolua KN, Gbolo BZ, Tshidibi JD, Tshibangu DST, Memvanga PB, Mpiana PT. Effect of Storage on the Bioactivity of Drepanoalpha ${ }^{\circledR}$ (An Anti-Sickle Cell Disease Polyherbal Formula) and Comparative Biochemical Profile of Different Batches. International Journal of Chemical and Biomolecular Science 4(4): 60-68, 2018.

[6] Ngbolua KN, Mpiana PT, Tshibangu DST, Mazasa PP, Gbolo BZ, Atibu EK, Kadima JN and Kasali FM. In vitro antisickling and radical scavenging activities of a poly-herbal formula $\left(\right.$ Drepanoalpha ${ }^{\circledR}$ ) in sickle cell erythrocyte and acute toxicity study in Wistar albinos rats. European Journal of Medicinal Plants. 2014; 4(10): 1251-67.

[7] Ngbolua KN, Mpiana PT. The possible role of a congolese polyherbal formula $\left(\right.$ Drepanoalpha ${ }^{\mathbb{B}}$ ) as source of epigenetic modulators in sickle cell disease: A hypothesis. J. of Advancement in Medical and Life Sciences. 2014; 2(1):1-3.

[8] Mpiana PT, Kasali FM, Bwirhonde F, Gbolo BZ, Tshibangu DST, Ngbolua KN, et al. Acute and sub-acute oral toxicity studies of Drepanoalpha ${ }^{\circledR}$ (a poly-herbal formula used in the management of sickle cell disease) in guinea-pig. British Journal of Pharmaceutical Research. 2016; 10(5): 1-8.

[9] Ngbolua KN, Tshidibi JD, Tshibangu DST, Memvanga PB, Gbolo BZ, Tshilanda DD, Mpiana PT. Drepanoalpha ${ }^{\mathbb{B}}$ : An Overview on the Quality Control Process and Standardization Feature of an Antisickling Herbal Drug from Democratic Republic of the Congo. J. of Modern Drug Discovery and Drug Delivery Research. 2016; V4I1. DOI: 10.15297/JMDDR. V4I1.01.

[10] Gbolo BZ, Asamboa LS, Bongo GN, Tshibangu DST, Kasali FM, Memvanga PB, Ngbolua KN, Mpiana PT. Bioactivity and chemical analysis of Drepanoalpha: An anti-sickle cell 
anemia poly-herbal formula from Congo-Kinshasa American Journal of Phytomedicine and Clinical Theurapetics. 2017; 5(1):1-5.

[11] Gbolo BZ, Tshibangu DST, Asamboa LT, Bongo NG, Kasali MF, Feza BV, Ngbolua KN, Mpiana PT. Sickle cell anemia therapeutic approach based on Drepanoalpha ${ }^{\mathbb{B}}$ : About 34 cases. Journal of Complementary and Alternative Medical Research 2017; 4 (2): 1-8.

[12] http://www.scnaturopathe.com/pages/analyse-quantique.html

[13] http://optumumsante.fr/analyse-quantique.htm

[14] https://hygiene-vital.com/analyseur-quantum-de-resonance-magnetic/

[15]GirotR, Begué P, Galacteros F. Sickle cell disease. John Libbey Eurotext Paris, 2003.

[16] Brugnara C, De Franceshi L, Alper SL. Inhibition of $\mathrm{Ca}^{2+}$ dependent $\mathrm{K}^{+}$transport and cell dehydratation in sickle erythrocytes by CLT and other imidazole derivatives. J. Clin. Invest.1993 ; 92: 520-526.

[17] Rifkind JM, Mohanty JG,Nagababu E. The pathophysiology of extracellular hemoglobin associated with enhanced oxidative reactions. Frontiers in Physiology 2015; 5: 1-7. doi: 10.3389/fphys.2014.00500.

\section{Appendix: Test results}

\begin{tabular}{|c|c|c|c|}
\hline \multirow{2}{*}{ Evaluated parameter } & \multicolumn{3}{|l|}{ value } \\
\hline & normal & $\mathrm{J}_{0}$ & $\mathbf{J}_{21}$ \\
\hline \multicolumn{4}{|l|}{ Systems cardiovascular and cerebrovascular } \\
\hline Blood viscosity & $48,264-65,371$ & 64,599 & 64,601 \\
\hline Cholesterol crystals & $56,749-67,522$ & 72,58 & 72,602 \\
\hline Blood lipids & $0,481-1,043$ & 0,607 & 0,623 \\
\hline Vascular resistance & $0,327-0,937$ & 1,417 & 1,423 \\
\hline Blood vessel elasticity & $1,672-1,978$ & 1,694 & 1,704 \\
\hline Myocardide blood demand & $0,192-0,412$ & 0,492 & 0,511 \\
\hline Blood infusion volume of the myocardia & $4,832-5,147$ & 5,095 & 5,111 \\
\hline Oxygen consumption of the myocardia & $3,321-4,244$ & 3,845 & 3,849 \\
\hline Heart rate & $1,338-1,672$ & 1,152 & 1,149 \\
\hline Ejection impedance of the left ventricle & $0,669-1,544$ & 1,229 & 1,237 \\
\hline Actual propulsion power of the left ventricular & $1,554-1,988$ & 1,09 & 1,094 \\
\hline Coronary artery elasticity & $1,553-2,187$ & 1,57 & 1,593 \\
\hline Coronary infusion tension & $11,719-18,418$ & 17,221 & 17,221 \\
\hline Elasticity of brain blood vessels & $0,708-1,942$ & 1,078 & 1,088 \\
\hline Brain blood supply situation & $6,138-21,396$ & 13,703 & 13,735 \\
\hline \multicolumn{4}{|l|}{ Gastrointestinal function } \\
\hline Pepsin secretion coefficient & $59,847-65,234$ & 59,827 & 59,837 \\
\hline Gastric motility factor & $58,425-61,213$ & 60,141 & 60,159 \\
\hline Gastric absorption coefficient & $34,367-35,642$ & 33,916 & 33,904 \\
\hline $\begin{array}{l}\text { Digestive motor coefficient of the small } \\
\text { intestine }\end{array}$ & $133,437-140,476$ & 136,858 & 136,879 \\
\hline Small intestine absorption coefficient & $3,572-6,483$ & 2,924 & 2,94 \\
\hline \multicolumn{4}{|l|}{ Function of the large intestine } \\
\hline $\begin{array}{l}\text { Coefficient of peristalsis function of the large } \\
\text { intestine }\end{array}$ & $4,572-6,483$ & 21,55 & 6,444 \\
\hline Colon absorption rate & $2,946-3,815$ & 10,273 & 3,781 \\
\hline
\end{tabular}




\begin{tabular}{|c|c|c|c|}
\hline $\begin{array}{l}\text { Bacteria coefficient } \\
\text { Intraluminal pressure coefficient }\end{array}$ & $\begin{array}{l}1,734-2,621 \\
1,173-2,297 \\
\end{array}$ & $\begin{array}{l}13,797 \\
26,291 \\
\end{array}$ & $\begin{array}{l}2,611 \\
26,287 \\
\end{array}$ \\
\hline \multicolumn{4}{|l|}{ Liver function } \\
\hline Protein metabolism & $116,34-220,621$ & 147,868 & 147,887 \\
\hline Energy production function & $0,713-0,992$ & 0,803 & 0,816 \\
\hline Detoxification function & $0,202-0,991$ & 0,221 & 0,224 \\
\hline Bile secretion function & $0,432-0,826$ & 0,436 & 0,444 \\
\hline Liver fat content & $0,097-0,419$ & 0,593 & 0,609 \\
\hline \multicolumn{4}{|l|}{ Gallbladder function } \\
\hline Serum-globulin (A/G) & $126-159$ & 142,833 & 142,835 \\
\hline Bilirubin Total (TBIL) & $0,232-0,686$ & 0,463 & 0,457 \\
\hline Alkaline Phosphatase (ALP) & $0,082-0,342$ & 0,289 & 0,305 \\
\hline Total bile acid serum (TBA) & $0,317-0,695$ & 0,483 & 0,489 \\
\hline Bilirubin (DBIL) & $0,218-0,549$ & 0,269 & 0,279 \\
\hline \multicolumn{4}{|l|}{ Pancreatic function } \\
\hline insulin & $2,845-4,017$ & 3,59 & 3,593 \\
\hline Pancreatic Polypeptide (PP) & $3,210-6,854$ & 4,28 & 4,296 \\
\hline Glucagon & $2,412-2,974$ & 2,762 & 2,778 \\
\hline \multicolumn{4}{|l|}{ Kidney function } \\
\hline Urobilinogen index & $2,762-5,424$ & 5,678 & 5,676 \\
\hline Uric acid index & $1,435-1,987$ & 1,845 & 1,829 \\
\hline Blood urea index (BUN) & $4,725-8,631$ & 9,514 & 9,524 \\
\hline Proteinuria index & $1,571-4,079$ & 2,572 & 2,6 \\
\hline \multicolumn{4}{|l|}{ Lung function } \\
\hline Vital capacity & $3348-3529$ & 5387,049 & 5387 \\
\hline Total lung capacity & $4301-4782$ & 4219,895 & 4220 \\
\hline Airway resistance & $1,374-1,709$ & 6,396 & 6,4 \\
\hline Arterial oxygen content & $17,903-21,012$ & 79,864 & 79,866 \\
\hline \multicolumn{4}{|l|}{ Cerveau } \\
\hline Blood irrigation of the brain & $143,37-210,81$ & 137,927 & 137,931 \\
\hline Cerebral arteriosclerosis & $0,103-0,642$ & 1,109 & 1,116 \\
\hline State of cranial nerves & $0,253-0,659$ & 1,252 & 0,641 \\
\hline Emotional index & $0,109-0,351$ & 3,477 & 3,496 \\
\hline Memory Index (ZS) & $0,442-0,817$ & 3,349 & 0,807 \\
\hline \multicolumn{4}{|l|}{ Bone mineral density } \\
\hline Osteoclast coefficient & $86,73-180,97$ & 838,012 & 838,013 \\
\hline Calciumrate & $0,209-0,751$ & 7,125 & 7,121 \\
\hline Degree of bone hyperplasia & $0,046-0,167$ & 0,227 & 0,243 \\
\hline Degree of osteoporosis & $0,124-0,453$ & 4,313 & 4,323 \\
\hline Bone mineral density & $0,433-0,796$ & 1,217 & 0,786 \\
\hline
\end{tabular}




\begin{tabular}{|c|c|c|c|}
\hline Degree of cervical calcification & $421-490$ & 2678,672 & 2678,682 \\
\hline Degree of lumbar calcification & $4,326-7,531$ & 74,906 & 74,903 \\
\hline Hyperostosis coefficient & $2,954-5,543$ & 0,155 & 2,976 \\
\hline Osteoporosis coefficient & $2,019-4,721$ & 0,885 & 2,032 \\
\hline Rheumatism coefficient & $4,023-11,627$ & 55,29 & 55,315 \\
\hline \multicolumn{4}{|l|}{ Bone growth index } \\
\hline Bone alkaline phosphatase & $0,433-0,796$ & 6,327 & 0,778 \\
\hline Ostéocalcine & $0,525-0,817$ & 5,752 & 0,812 \\
\hline Long Bone Healing Status & $0,713-0,992$ & 1,541 & 0,982 \\
\hline Health of short bone cartilage & $0,202-0,991$ & 0,237 & 0,25 \\
\hline Epiphysary line & $0,432-0,826$ & 6,043 & 0,816 \\
\hline \multicolumn{4}{|l|}{ Sugar in the blood } \\
\hline Insulin secretion coefficient & $2,967-3,528$ & 12,421 & 12,412 \\
\hline Blood glucose coefficient & $2,163-7,321$ & 1,286 & 1,297 \\
\hline Sugar coefficient in urine & $2,204-2,819$ & 6,8 & 6,815 \\
\hline \multicolumn{4}{|c|}{ Mineral elements and Oligo-elements } \\
\hline Calcium & $1,219-3,021$ & 0,058 & 0,062 \\
\hline Do & $1,151-1,847$ & 2,634 & 1,829 \\
\hline Zinc & $1,143-1,989$ & 4,007 & 1,984 \\
\hline Selenium & $0,847-2,045$ & 2,238 & 2,04 \\
\hline phosphorus & $1,195-2,134$ & 10,936 & 2,129 \\
\hline Potassium & $0,689-0,987$ & 5,411 & 0,982 \\
\hline magnesium & $0,568-0,992$ & 1,777 & 0,973 \\
\hline Copper & $0,474-0,749$ & 4,084 & 0,739 \\
\hline Cobalt & $2,326-5,531$ & 18,245 & 5,518 \\
\hline Manganese & $0,497-0,879$ & 1,831 & 0,874 \\
\hline Iodine & $1,421-5,490$ & 39,665 & 5,488 \\
\hline Nickel & $2,462-5,753$ & 19,551 & 5,736 \\
\hline Fluor & $1,954-4,543$ & 17,917 & 4,529 \\
\hline Molybdenum & $0,938-1,712$ & 1,481 & 1,491 \\
\hline Vanadium & $1,019-3,721$ & 30,35 & 3,706 \\
\hline Tin & $1,023-7,627$ & 47,264 & 7,617 \\
\hline Silicon & $1,425-5,872$ & 11,586 & 5,862 \\
\hline Strontium & $1,142-5,862$ & 11,568 & 5,857 \\
\hline Bore & $1,124-3,453$ & 17,806 & 3,443 \\
\hline \multicolumn{4}{|l|}{ Vitamin } \\
\hline Vitamin A & $0,346-0,401$ & 0,576 & 0,396 \\
\hline Vitamin $B_{1}$ & $2,124-4,192$ & 3,402 & 3,411 \\
\hline Vitamin $B_{2}$ & $1,549-2,213$ & 4,973 & 2,208 \\
\hline Vitamin B3 & $14,477-21,348$ & 84,544 & 21,348 \\
\hline Vitamin $B_{6}$ & $0,824-1,942$ & 0,307 & 0,307 \\
\hline Vitamin $B_{12}$ & $6,428-21,396$ & 123,552 & 21,391 \\
\hline
\end{tabular}




\begin{tabular}{|c|c|c|c|}
\hline Vitamin C & $4,543-5,023$ & 26,169 & 5,013 \\
\hline Vitamin $\mathrm{D}_{3}$ & $5,327-7,109$ & 13,574 & 7,093 \\
\hline Vitamins E & $4,826-6,013$ & 13,151 & 6,008 \\
\hline Vitamin K & $0,717-1,486$ & 6,795 & 1,472 \\
\hline \multicolumn{4}{|l|}{ Amino acid } \\
\hline Lysine & $0,253-0,659$ & 2,932 & 2,965 \\
\hline Tryptophan & $2,374-3,709$ & 4,183 & 4,175 \\
\hline Phenylalanine & $0,731-1,307$ & 1,122 & 1,124 \\
\hline Methionine & $0,432-0,826$ & 0,617 & 0,614 \\
\hline Threonine & $0,422-0,817$ & 1,47 & 1,481 \\
\hline Isoleucine & $1,831-3,248$ & 17,471 & 17,481 \\
\hline Leucine & $2,073-4,579$ & 31,952 & 31,951 \\
\hline Valine & $2,012-4,892$ & 11,052 & 11,059 \\
\hline Histidine & $2,903-4,012$ & 10,927 & 10,923 \\
\hline Arginine & $0,710-1,209$ & 13,471 & 13,496 \\
\hline \multicolumn{4}{|l|}{ Coenzymes et oligopeptide } \\
\hline Nicotinamide & $2,074-3,309$ & 18,299 & 3,302 \\
\hline Biotin & $1,833-2,979$ & 9,114 & 2,974 \\
\hline Pantothenic acid & $1,116-2,101$ & 5,947 & 2,096 \\
\hline Folic acid & $1,449-2,246$ & 7,032 & 2,239 \\
\hline Coenzyme Q10 & $0,831-1,588$ & 0,844 & 0,878 \\
\hline Glutathione & $0,726-1,281$ & 2,677 & 1,271 \\
\hline \multicolumn{4}{|l|}{ Endocrine system } \\
\hline Thyroid secretion index & $2,954-5,543$ & 9,418 & 5,538 \\
\hline Parathyroid secretion index & $2,845-4,017$ & 2,498 & 2,524 \\
\hline Index ofadrenal heaths & $2,412-2,974$ & 10,815 & 2,959 \\
\hline Hypophysis secretion index & $2,163-7,34$ & 2,132 & 2,164 \\
\hline Pineal secretion index & $3,210-6,854$ & 37,457 & 6,844 \\
\hline Thymus secretion index & $2,967-3,528$ & 20,559 & 3,523 \\
\hline Glandular secretion index & $2,204-2,819$ & 12,235 & 2,8 \\
\hline \multicolumn{4}{|l|}{ Immune system } \\
\hline Lymph node index & $133,437-140,47$ & 787,062 & 787,073 \\
\hline Immune Index hasmygdal & $0,124-0,453$ & 1,288 & 0,448 \\
\hline Bone marrow index & $0,146-3,218$ & 16,591 & 3,208 \\
\hline Rate index & $34,367-35,642$ & 253,757 & 35,637 \\
\hline Index Thymus & $58,425-61,213$ & 3,773 & 3,784 \\
\hline Index immunoglobulin & $3,712-6,981$ & 1,489 & 1,503 \\
\hline Respiratory Immune Index & $3,241-9,814$ & 83,932 & 9,809 \\
\hline Gastrointestinal immune index & $0,638-1,712$ & 7,653 & 1,702 \\
\hline Mucous membrane immune index & $4,111-18,741$ & 12,858 & 12,866 \\
\hline \multicolumn{4}{|l|}{ Thyroid } \\
\hline Thyroxine libre (FT4) & $0,103-0,316$ & 0,841 & 0,849 \\
\hline Thyroglobulin & $0,114-0,202$ & 1,83 & 1,843 \\
\hline Anticorps anti-thyroglobuline & $0,421-0,734$ & 3,185 & 0,729 \\
\hline Triiodothyronine (T3) & $0,161-0,308$ & 1,583 & 1,593 \\
\hline \multicolumn{4}{|l|}{ Qualité physique Base } \\
\hline Response capacity & $59,786-65,424$ & 288,094 & 65,419 \\
\hline Mental capacity & $58,715-63,213$ & 21,1 & 21,11 \\
\hline
\end{tabular}




\begin{tabular}{|c|c|c|c|}
\hline Lack ofe & $33,967-37,642$ & 323,023 & 37,637 \\
\hline Hypoxia & $133,642-141,476$ & 1208,137 & 141,467 \\
\hline $\mathrm{pH}$ & $3,156-3,694$ & 6,094 & 6,111 \\
\hline \multicolumn{4}{|l|}{ Obesity } \\
\hline Lipid metabolism coefficient & $1,992-3,713$ & 3,954 & 3,708 \\
\hline Fat tissue colour coefficient (from Brown) & $2,791-4,202$ & 11,555 & 4,197 \\
\hline Insulin increase coefficient (hyper insulin) & $0,097-0,215$ & 1,227 & 1,237 \\
\hline Hypothalamus core coefficient & $0,332-0,626$ & 5,547 & 5,549 \\
\hline Triglyceride content coefficient & $1,341-1,991$ & 1,216 & 1,356 \\
\hline \multicolumn{4}{|l|}{ Skin } \\
\hline Free radical skin indexes & $0,124-3,453$ & 0,618 & 0,608 \\
\hline Index of collagen in the skin & $4,471-6,079$ & 8,456 & 6,069 \\
\hline Fat index in the skin & $14,477-21,348$ & 136,897 & 136,913 \\
\hline Skin immunity index & $1,035-3,230$ & 2,232 & 2,251 \\
\hline Skin moisture index & $0,218-0,953$ & 18,854 & 18,855 \\
\hline Lost skin moisture & $2,214-4,158$ & 42,595 & 42,604 \\
\hline Red blood trace index under the skin & $0,824-1,942$ & 12,278 & 12,282 \\
\hline Skin elasticity index & $2,717-3,512$ & 1,255 & 1,267 \\
\hline Skin melanin index & $0,346-0,501$ & 3,917 & 3,914 \\
\hline Skin Keratinization Index & $0,842-1,858$ & 15,384 & 15,388 \\
\hline \multicolumn{4}{|l|}{ Eyes } \\
\hline Pockets under the eyes & $0,510-3,109$ & 28,379 & 28,379 \\
\hline Collagen Eye Wrinkles & $2,031-3,107$ & 3,842 & 3,102 \\
\hline Dark circles & $0,831-3,188$ & 1,808 & 1,839 \\
\hline Lymphatic obstruction & $1,116-4,101$ & 7,861 & 7,859 \\
\hline subsiding & $0,233-0,559$ & 1,915 & 1,926 \\
\hline Edema & $0,332-0,726$ & 5,341 & 5,345 \\
\hline Eye cell activity & $0,118-0,892$ & 4,8 & 4,801 \\
\hline Visual fatigue & $2,017-5,157$ & 2,219 & 2,23 \\
\hline \multicolumn{4}{|l|}{ Collagen } \\
\hline Eyes & $6,352-8,325$ & 23,258 & 8,315 \\
\hline Dentition (Dents) & $7,245-8,562$ & 4,055 & 4,063 \\
\hline Hair and skin & $4,533-6,179$ & 15,301 & 6,169 \\
\hline Endocrine system & $6,178-8,651$ & 45,077 & 8,641 \\
\hline $\mathrm{C}$ irculatory device & $3,586-4,337$ & 2,351 & 2,368 \\
\hline Igestif device & $3,492-4,723$ & 17,074 & 4,718 \\
\hline Immune system & $3,376-4,582$ & 8,911 & 4,581 \\
\hline Engine system & $6,458-8,133$ & 26,619 & 8,125 \\
\hline Fabric ofthe muscles & $6,552-8,268$ & 36,164 & 8,265 \\
\hline Big metabolism & $6,338-8,368$ & 15,757 & 8,358 \\
\hline Cellular detoxification & $6,187-8,466$ & 10,234 & 8,461 \\
\hline Reproductive device & $3,778-4,985$ & 9,109 & 4,975 \\
\hline Nervous system & $3,357-4,239$ & 2,059 & 2,054 \\
\hline
\end{tabular}




\begin{tabular}{|c|c|c|c|}
\hline Urinary device & $6,256-8,682$ & 46,912 & 8,672 \\
\hline \multicolumn{4}{|l|}{ Main and collateral channels } \\
\hline Lung meridian & $48,264-65,371$ & 424,114 & 65,361 \\
\hline Meridian of the large intestine & $56,749-67,522$ & 214,753 & 67,512 \\
\hline Meridian of the stomach & $0,481-1,043$ & 0,031 & 0,031 \\
\hline Meridian of the heart & $1,672-1,978$ & 0,162 & 0,215 \\
\hline Meridian of the small intestine & $0,192-0,412$ & 5,539 & 5,529 \\
\hline Meridian of the bladder & $4,832-5,147$ & 27,934 & 5,142 \\
\hline Meridian of the kidneys & $3,321-4,244$ & 10,512 & 4,184 \\
\hline Meridian of the pericardy & $1,338-1,672$ & 1,282 & 1,293 \\
\hline Shaoyang triple burner meridian & $0,669-1,544$ & 7,458 & 1,534 \\
\hline Gallbladder Meridian & $1,554-1,988$ & 6,246 & 1,958 \\
\hline Liver meridian & $1,553-2,187$ & 7,259 & 2,177 \\
\hline Jen May & $11,719-18,418$ & 19,135 & 18,408 \\
\hline Meridian Governor & $0,708-1,942$ & 14,524 & 1,855 \\
\hline Vital meridian & $6,138-21,396$ & 121,802 & 21,387 \\
\hline Tai more & $5,733-7,109$ & 26,706 & 7,033 \\
\hline \multicolumn{4}{|l|}{ Heart and brain pulses } \\
\hline Race index & $60,735-65,396$ & 600,525 & 600,54 \\
\hline Systolic volume (VS) & $63,012-67,892$ & 195,026 & 67,882 \\
\hline Peripheral cardiac resistance (RRT) & $0,983-1,265$ & 3,059 & 3,033 \\
\hline Pulse wave coefficient $\mathrm{K}$ & $0,316-0,401$ & 0,287 & 0,271 \\
\hline Cerebrovascular blood oxygen saturation rate & $0,710-1,109$ & 2,745 & 1,077 \\
\hline Volume of cerebrovascular oxygen $\left(\mathrm{CaCO}_{3}\right)$ & $7,880-10,090$ & 4,044 & 3,983 \\
\hline Cerebrovascular Oxygen Pressure $(\mathrm{PaO} 2)$ & $5,017-5,597$ & 48,354 & 5,579 \\
\hline \multicolumn{4}{|l|}{ Blood lipids } \\
\hline Blood viscosity & $4,131-4,562$ & 19,253 & 19,242 \\
\hline Total Cholesterol (CT) & $1,833-2,979$ & 0,809 & 1,843 \\
\hline Triglycerides (TG) & $1,116-2,101$ & 1,413 & 1,382 \\
\hline High-density lipoprotein (C-HDL) & $1,449-2,246$ & 9,123 & 9,147 \\
\hline Low-density lipoprotein (C-LDL) & $0,831-1,588$ & 7,301 & 1,578 \\
\hline Neutral fat (MB) & $0,726-1,281$ & 13,072 & 13,103 \\
\hline Complexes immuns circulants (CIC) & $13,012-17,291$ & 12,94 & 13,027 \\
\hline \multicolumn{4}{|l|}{ gynaecology } \\
\hline Estrogènand & $3,296-8,840$ & 11,084 & 8,828 \\
\hline Gonadotropine & $4,886-8,931$ & 20,534 & 8,93 \\
\hline Prolactine & $3,142-7,849$ & 8,101 & 7,846 \\
\hline Progestérone & $6,818-16,743$ & 64,712 & 16,724 \\
\hline Vaginitis coefficient & $2,204-2,819$ & 15,159 & 15,173 \\
\hline Coefficient de PID & $1,348-3,529$ & 23,554 & 23,559 \\
\hline Appendicitis coefficient & $2,301-4,782$ & 26,83 & 26,838 \\
\hline Cervicitis coefficient & $2,845-4,017$ & 4,815 & 4,81 \\
\hline
\end{tabular}


Britain International of Exact Sciences (BIoEx) Journal

ISSN: 2686-1208 (Online), 2686-1216 (Print)

Vol. 1 , No. 1, September 2019, Page: 36-48

\begin{tabular}{|c|c|c|c|}
\hline Ovarian cyst coefficient & $2,012-4,892$ & 41,143 & 41,16 \\
\hline \multicolumn{4}{|l|}{ to be } \\
\hline Hyperplasia coefficient of the mammary glands & $0,202-0,991$ & 0,895 & 0,895 \\
\hline Acute mastitis coefficient & $0,713-0,992$ & 2,947 & 2,973 \\
\hline Chronic mastitis coefficient & $0,432-0,826$ & 5,477 & 5,462 \\
\hline Endocrine dyscrasia coefficient & $1,684-4,472$ & 8,313 & 8,32 \\
\hline Breast fibroadenoma coefficient & $0,433-0,796$ & 1,277 & 1,296 \\
\hline \multicolumn{4}{|l|}{ Menstrual cycle } \\
\hline Hormone beta & $2,942-3,407$ & 29,623 & 3,401 \\
\hline Protein reflection & $4,713-5,345$ & 38,685 & 5,34 \\
\hline Fibrinogen & $2,807-3,294$ & 2,508 & 2,526 \\
\hline Sedimentation rate & $6,326-8,018$ & 8,278 & 8,013 \\
\hline \multicolumn{4}{|l|}{$T D A H$} \\
\hline Oxygen-hydroxy-phenyl-ethanol & $1,163-2,206$ & 13,449 & 2,201 \\
\hline GE Neurotransmitters & $0,753-0,972$ & 3,168 & 0,963 \\
\hline Vanilloid & $0,232-0,981$ & 5,238 & 0,978 \\
\hline Créatine kinase & $0,150-0,240$ & 1,071 & 1,074 \\
\hline
\end{tabular}

